\title{
Small Kinetochore-Associated Protein
}

National Cancer Institute

\section{Source}

National Cancer Institute. Small Kinetochore-Associated Protein. NCI Thesaurus. Code C119654.

Small kinetochore-associated protein (316 aa, $\sim 35 \mathrm{kDa}$ ) is encoded by the human KNSTRN gene. This protein plays a role in the progression of mitosis. 